\title{
Future climate change in the Mediterranean area: implications for water use and weed management
}

\author{
Stella Lovelli, ${ }^{1}$ Michele Perniola, ${ }^{1}$ Emanuele Scalcione, ${ }^{2}$ Antonio Troccoli, ${ }^{3}$ Lewis H. Ziska ${ }^{4}$ \\ ${ }^{1}$ Dipartimento di Scienze dei Sistemi Colturali, Forestali e dell'Ambiente, Università della \\ Basilicata, Potenza, Italy \\ ${ }^{2}$ Doctoral School of Crop System, Forestry and Environmental Sciences, Università della \\ Basilicata, Potenza, Italy \\ ${ }^{3}$ Consiglio per la ricerca e la sperimentazione in agricoltura - Centro di ricerca per la cerealicoltura \\ (CRA-CER), Foggia, Italy \\ ${ }^{4}$ USDA, Agricultural Research Service, Crop Systems and Global Change Laboratory, Beltsville, \\ MD, USA
}

\begin{abstract}
Results obtained within research activity from the Climesco Italian Project are summarized. These results suggest that in regards to the impact of climate change in the Mediterranean area, a decrease of water availability and a more frequent occurrence of drought periods are expected. In order to describe the main effects of climate change on water use in some agro-ecosystems in the Mediterranean area we showed that the Penman-Monteith equation can be modified to simulate future changes in reference evapotranspiration by recalibration of the crop resistive parameter. Moreover, the use of adjusted crop coefficients $(\mathrm{Kc}$ ) can help quantify the climate change impact on water use for irrigated crops grown in Southern Italy and elsewhere in the Mediterannean. For this region temperature rise and the concomitant expected rainfall reduction may lead to an increase yearly potential water deficits. For autumn-spring crops a further increase of water deficit is not expected. In contrast for a significant increase of water
\end{abstract}

Correspondence: Stella Lovelli, Dipartimento di Scienze dei Sistemi Colturali, Forestali e dell'Ambiente, Università della Basilicata, viale dell'Ateneo Lucano 10, 85100 Potenza, Italy. E-mail: stella.lovelli@unibas.it

Key words: water balance, irrigation requirements, climate scenario, $\mathrm{CO}_{2}$ effect, weed management

Acknowledgements: this research was funded by CLIMESCO Evolution of cropping systems as affected by climate change project, contract n. 285, 20/02/2006 (Ministry for Education, University and Research).

Received for publication: 10 March 2011.

Accepted for publication: 20 June 2011.

CC Copyright S. Lovelli et al., 2012

Licensee PAGEPress, Italy

Italian Journal of Agronomy 2012; 7:e7

doi:10.4081/ija.2012.e7

This article is distributed under the terms of the Creative Commons Attribution Noncommercial License (by-nc 3.0) which permits any noncom mercial use, distribution, and reproduction in any medium, provided the original author(s) and source are credited. deficit, and thus of irrigation needs, is expected for spring-summer crops. Another aspect considered in this review is how in the Mediterranean area, drought conditions and warmer temperatures will alter the competitive balance between crops and some weed species. We report experimental data showing how weed aggressiveness and competition is already increasing due to warmer temperatures in the Mediterranean region.

\section{Introduction}

The IPCC third assessment report (IPCC 2001) emphasized that climate change was likely to be associated with extremes of water availability. Indeed, drought in some area of the world may become so widespread and so severe in the coming decades that current drought indices may no longer work properly in quantifying future drought (Dai, 2010).

However, because of the coarseness of existing models, it is unclear which regions are likely to experience drought in the future. That is, from a hydrological standpoint, not all regions will respond in a similar fashion to recent and projected increases in global mean temperature. From this point of view, one of the most critical regions is the Mediterranean basin, where a non uniform and discontinuous warming was identified and a strong east-west differentiation in temperature trends was well documented (Kostopoulou and Jones, 2005). A number of researchers have, in fact, suggested that significant impacts are likely in southern Europe and the Mediterranean, where warming greater than the average is expected, mostly in summer, with a subsequent increase in heat waves and a significant rainfall decrease (IPCC, 2007; Olesen and Bindi, 2002, Vitale et al., 2010).

Because agriculture is recognized globally as a principle user of water for irrigation; agriculture in the Mediterranean region will be affected by climatic change both directly (changes in precipitation and water sources, changes in the evapotranspiration rate), and indirectly (greater competition with weeds) (Vergni and Todisco, 2010). Implementation of agronomic techniques regarding cultivation, water use, nutrient and weed management could reduce the impact of increasing drought frequency in the Mediterranean region. In this context it is of paramount importance to simulate the future changes of crop evapotranspiration and future irrigation requirement of crops usually cultivated in the Mediterranean area. In addition, it will be 
necessary to understand the impact of temperature and droughts on Mediterranean agro-ecosystems in general and on weed management, in particular.

\section{Temperature and drought impacts on potential water use of crops in the Mediterranean}

Crop water requirement is function of several climatic parameters, including rainfall, radiation, temperature, humidity and wind speed. Thus, variation in climatic parameters are also likely to affect evapotranspiration (Goyal, 2004). However biological factors such as plant growth, canopy structure and stomatal responses to the environment (Moratiel et al., 2010) will also influence water use.

At the individual plant level, $\mathrm{CO}_{2}$ induced changes in stomatal conductance, could result in reduction in water use, and an increase in carbon assimilation, with an overall increase in water use efficiency. However, at the canopy level, a decrease in transpiration also results in a lower thermoregulatory effect and consequently an increase in temperature. It is unclear if, in turn, the increase in canopy temperature is sufficient to negate any stomatal induced changes in transpiration (Bernacchi et al., 2007). At the whole canopy level, the latter effects could potentially nullify the reduction of stomatal conductance observed in single leaves (Polley, 2002; Bernacchi et al., 2007). On these latter aspects regarding canopy water use and efficiency there is still uncertainty (Bernacchi et al., 2007).

Actually, at the canopy level, both abiotic and biotic variables intervene, including surface layer and mixed layer feedback as well as stomatal conductance and canopy microclimate (Wilson et al., 1999). These variables, in turn, are related to leaf area, canopy temperature, irradiance, wind speed, vapour pressure deficit (VPD), and canopy architecture (McNaughton, 1983; Baldocchi, 1994; Morecroft and Roberts, 1999). Overall, with respect to feedbacks and enhanced leaf area anticipated with rising carbon dioxide, the simulated decrease in ET at the canopy level is likely to be significantly less than the decrease in conductance observed for single leaves (Wilson et al., 1999; Bernacchi et al., 2007)

Although assessments of $\mathrm{CO}_{2}$, climate change and water use have been conducted elsewhere, principally North America (e.g. Kimball, 2004), there are not similar data for the Mediterranean region. Considering the complexities of $\mathrm{CO}_{2}$, climate and evapotranspiration we estimated changes in reference evapotranspiration (ETo) in the Mediterranean area as a consequence of climate change using the standardized Penman-Monteith (PM) equation (Allen et al., 1998; 2006). Our approach differed from other assessments (e.g., Rosenberg et al., 1990; Moratiel et al., 2010), in our consideration of canopy conductance (Lovelli et al., 2010b).

Taking into account published values regarding atmospheric $\mathrm{CO}_{2}$ on stomatal conductance (Ainsworth and Long, 2006) (gs), we considered the effect on stomatal and canopy conductance (Lovelli et al., 2010b). We also considered the temperature increment effect on the reference evapotranspiration (ETo) variation, comparing the evapotranspiration assessment obtained using the PM equation with that obtained by modifying the canopy resistance parameter (Lovelli et al., 2010b). These data suggest that any reduction in stomatal conductance is able to control the effect of climate change only for a narrow set of temperatures $\left(0-2^{\circ} \mathrm{C}\right.$; Figure 1$)$. For each value of the daily mean air temperature, Figure 1 indicates that plant adjustment, partially closing stomata, reduces water use. This adaptative plant response to higher levels of atmospheric $\mathrm{CO}_{2}$ concentration may be negated by an increase in air temperature and seubsequent increase in evapotranspiration rate. This rise would be likely to occur in an environment with a hot-arid climate such as the Mediterranean. This approach may be particularly effective in evaluating climate change driven effects on crop water use because it incorporates climate change effects through the PenmanMonteith equation, recalibrated with respect to canopy conductance.

In simulating the measured historical data (1961-2006 for Southern Italy), our analysis showed that from 1985 on, the annual average temperature followed an increasing trend and, moreover, the rainfall regime changed compared to the measured trend of the previous years. Taking the 1985 as a reference year, the annual mean temperature has risen by $1.3^{\circ} \mathrm{C}$ in 2006 and a further increment of $4.8^{\circ} \mathrm{C}$ should be expected in 2071 according to the data from the A2 simulation (Emissions Scenarios A2, Nakicenovic et al., 2000). Despite signficant annual variability, a statistical analysis of rainfall indicated a tendency for a slight decrease.

Recent analysis have suggested that temperature is more likely to change consistently for a given region than precipitation (Lobell et al., 2011). Given that expectations regarding future rainfall trends are still greatly uncertain (Döll, 2002) this will affect forecasts about crop water use in future climate scenarios since such forecasts strongly depend on rainfall timing and amounts.

\section{Impact of climate change on crop coefficients}

Some regional climate scenarios show anticipation of drier summers over continental Europe (Giorgi et al., 2001; Rowell and Jones, 2006). Consequently drier weather could lead to more water stress and higher demand for water resources by crops (Fink et al., 2004). Given the potential scarcity of water, proper irrigation scheduling to maximize production while minimizing water use becomes critical. One strategy to achieve this is to improve estimates of crop evapotranspiration. This can be accomplished by deriving the reference evapotranspiration (ETo) through the Penman-Monteith equation and multiplying the obtained value by the crop coefficient (ETc=ETo $\times \mathrm{Kc}$ ) (Allen et al., 1998). However, crop coefficients, also vary as a function of climate (Allen et al., 1998), consequently determination of a more accurate crop coefficient - one that reflects climatic inputs could improve irrigation efficiency. However, at present, there are few studies concerning the impact of increasing temperature on crop coefficients.

Clearly, temperature has a direct effect on the geographic distribu-

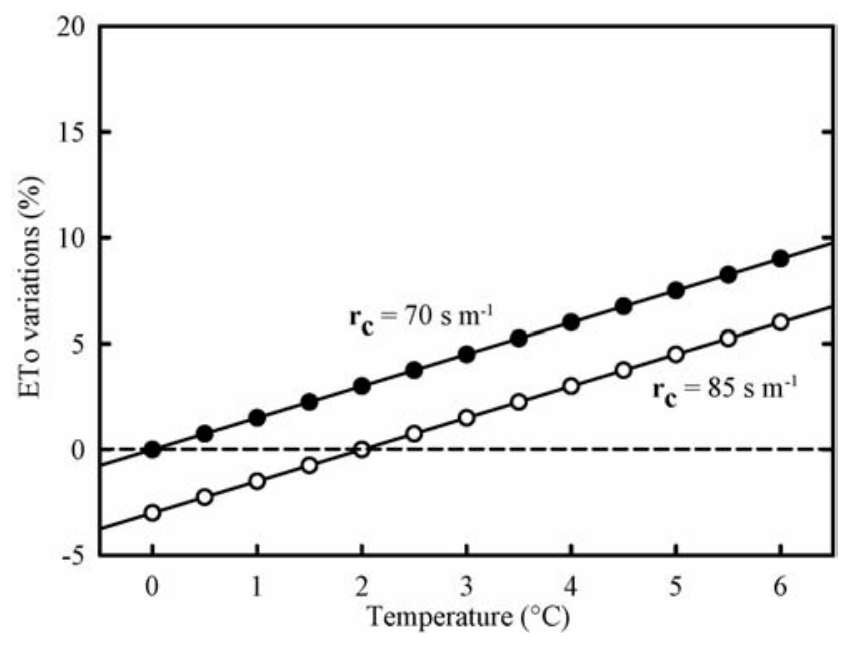

Figure 1. Percentage variations of reference evapotranspiration (ETo) as a function of projected temperature increases, calculated by the Penman-Monteith equation (full circles) and with a recalibration of the canopy resistance parameter (rc), (empty circles), (from Lovelli et al., 2010b). 
tion of crops. A northbound shift of some crop growing areas is expected in response to predicted increases in temperature in Mediterranean regions (Bindi, 1992; 1996; 2000). Moreover crop production cycles may shorten, since temperature increases the thresholds for the beginning of the growing season and accelerates harvests (Porter, 2005; Moratiel et al., 2010). More specifically, in seed crops with determined flowering, the achievement of ripening time is closely linked to temperature and day length. Thus, a thermal increase will lead to a shortening of the growing cycle, because increasing temperature results in an accleration of the reproductive phase and shortening of the crop life cycle (Peiris et al., 1996). Because global warming is expected to have an impact on crop phenology any modification may have a significant effect on crop coefficients not accounted for in most estimates of ET.

We considered the climate change impact on water use of major crops grown in the Mediterranean area (wheat, tomato, broccoli and muskmelon). The impact of climate changes on phenological phase length was assessed by the Growing Degree Days (GDD simulation). In the future scenario for the crop evapotranspiration (ETc) assessment, we considered the $\mathrm{CO}_{2}$ effect recalibrating the canopy resistance $\left(\mathrm{r}_{\mathrm{s}}\right)$ parameter and the temperature effect by adjusting crop coefficients for meteorological inputs and phenological phase duration. In our simulation we showed that a further adjustment of Kc that takes into account global warming impacts on crop phase length, is necessary to achieve a more accurate estimate of water use. By adjusting Kc according to the
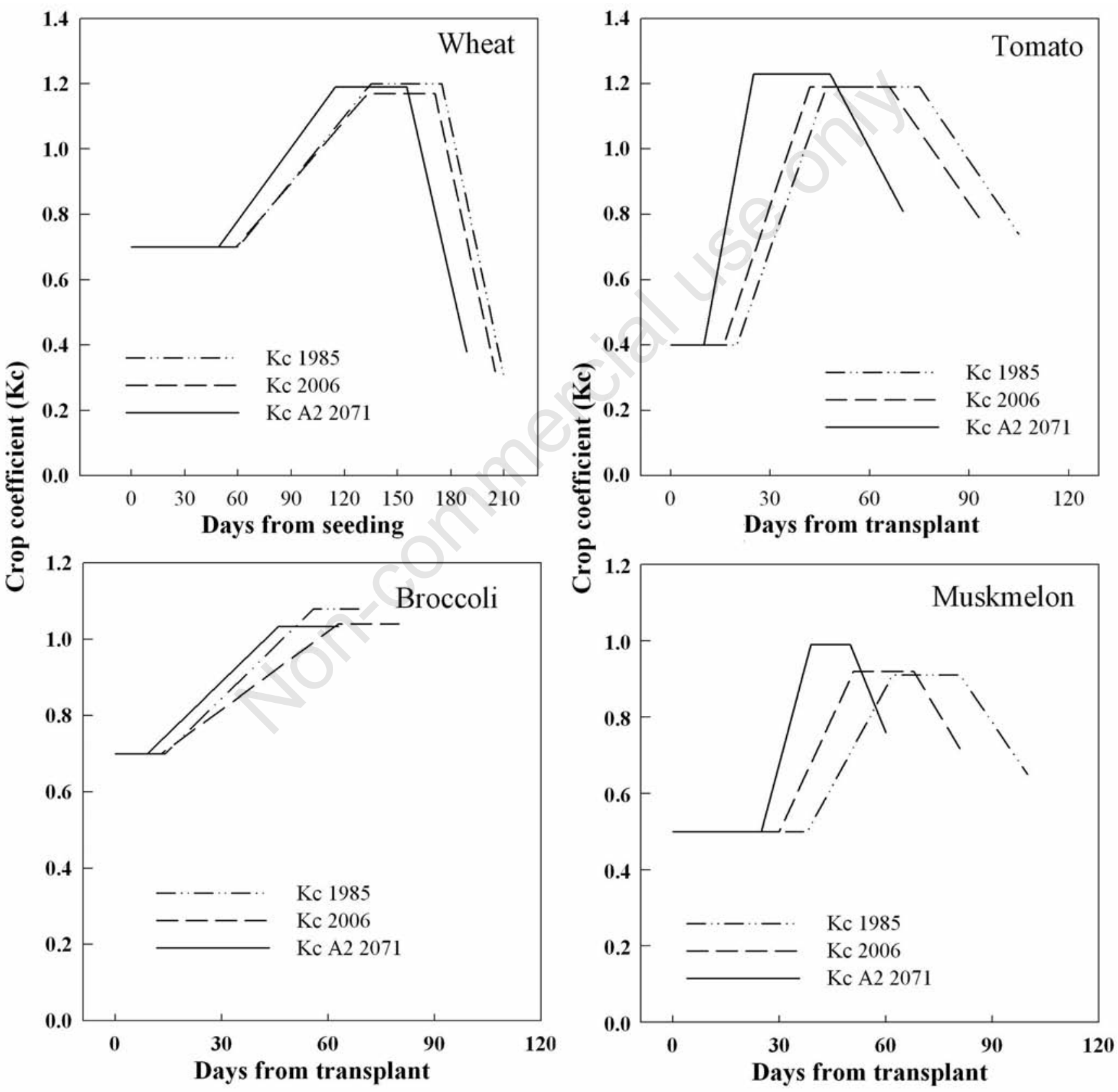

Figure 2. Daily pattern of crop coefficients (Kc) for wheat, tomato, broccoli and muskmelon in 1985, 2006 and for the IPCC A2 scenario for 2071, (modified from Lovelli et al., 2010b). 
recent and projected changes in climate using the IPCC A2 scenario, we assessed irrigation requirements of wheat, broccoli, tomato and muskmelon (Figure 2). In general, our results are in accordance with Döll (2002) who states that simulations of irrigation requirements under climate change scenarios, may lead to a shift in the optimal growing period, often by a month or more into the winter season with potential changes in the cropping pattern. As regard to autumn-spring crops such as wheat and broccoli, a further increase in water deficits is not expected. The decrease of water use (due to the reduction of crop cycle length and, to some extent, to the stomatal closure), in the case of the most favourable rainfall distribution, will likely compensate the higher environmental evapotranspirative demand caused by temperature increase in this instance. However, for the spring-summer crops, (e.g., tomato and muskmelon), a significant increase of water deficits, and subsequent irrigation, is expected.

\section{Climate change and water competition between weeds and crops}

Weeds impose limitations on crop productivity by competing for resources. One such resource is, of course, water. How weeds will respond to climate change, particularly in regards to water use, is another essential factor in determining irrigation needs and efficiency.

Rising atmospheric $\mathrm{CO}_{2}$ and climate change are likely to have a significant impact on geographical distribution of weeds and on the severity of weed infestation (Cobb and Reade, 2010). The endemic ability of weeds to adjust phenotypes quickly to environmental change may provide a significant competitive advantage in agro-ecosystems (Cobb and Reade, 2010). How weeds respond to climatic change may, in turn, have significant implications for chemical control of weeds in agriculture (Ziska, 2010). For example rising $\mathrm{CO}_{2}$ has been shown to reduce the efficacy of glyphosate for Canadian thistle (Cirsium arvense) control (Ziska et al., 2004). Temperature and $\mathrm{CO}_{2}$ may also favour weed ruderality in terms of seed quantity and seed set (Benvenuti, 2009). In addition, the evolutionary rate in the development of herbicide resistance has been demonstrated to be affect by temperature and soil water availability (Cobb and Reade, 2010).

From the point of view of crop weed competition, climate may bring about two contrasting responses. On one hand, weeds and crops may differ in photosynthetic pathway. This may be significant because the C3 pathway is anticipated to show a stronger growth and photosynthetic response than the $\mathrm{C} 4$ pathway due to the $\mathrm{CO}_{2}$ concentrating mechanism of the latter. In contrast, warmer temperatures could favour the C4 photosynthetic pathway. Since there are a number of $\mathrm{C} 4$ crops (corn, sorghum millet) and weeds (pigweed, nutsedge), the effect of $\mathrm{CO}_{2}$ and/or climate on crop losses due to weeds is difficult to predict. As we showed for pigweed in the Mediterranean environment, photosynthesis is not completely saturated for $\mathrm{CO}_{2}$. In fact, as Figure 3 clearly shows, in pigweed, a common weed in Mediterranean regions, the operating $\mathrm{Ci}$ of photosynthesis under ambient $\mathrm{CO}_{2}$ concentration is below the inflexion point of the $\mathrm{A} / \mathrm{Ci}$ curve. This is an important result that could affect competition and increase weed aggressiveness towards crops in the Mediterranean agro-ecosystems (Lovelli et al., 2010c).

If, as seems likely, that $\mathrm{CO}_{2}$ and/or climatic change will alter the demographics, biology and management of agronomic weeds, water competition is also likely to increase. For example, with respect to water competition our data showed that $\mathrm{C} 4$ weeds, such as pigweed, are more drought resistant than pepper and bindweed, C3 weeds (Figure 4). Hence for a given amount of soil water, C4 weeds could develop a larger canopy, grow more root mass and produce more seeds than their C3 competitors (Ludlow, 1985; Long, 1999; Grise, 1996). The relative impact of this, in turn, on water loss, water requirements, and potential changes in crop coefficients has not been sufficiently addressed.

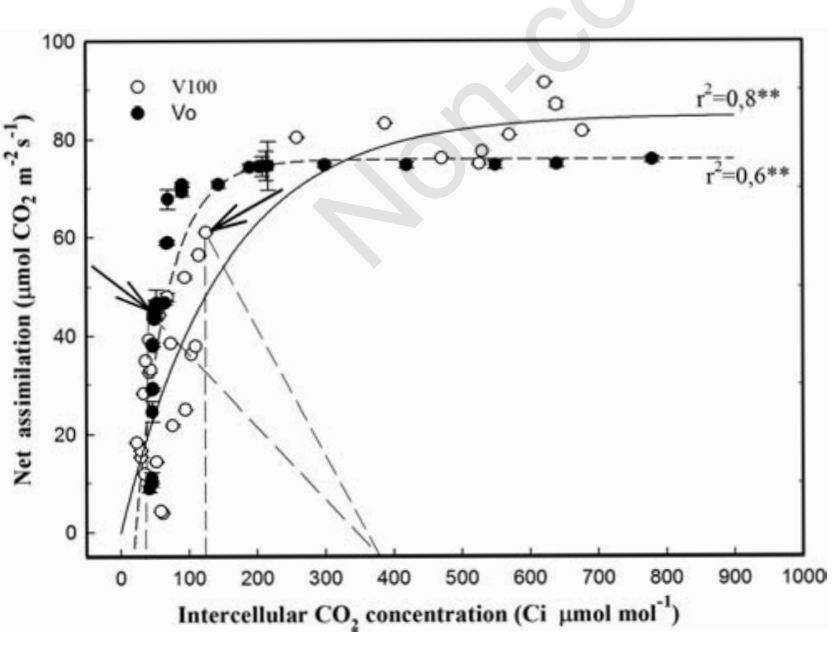

Figure 3. Response of leaf photosynthesis (measured as leaf $\mathrm{CO}_{2}$ assimilation rate, $\mathrm{A}$ ) to a range of internal $\mathrm{CO}_{2}$ concentration $(\mathrm{Ci})$ for single leaves of Amaranthus retroflexus $\mathrm{L}$. With irrigation (V100, open symbols, $n=4)$ and not irrigated (V0, closed symbols, $n=4)$. Solid line and dashed lines for the irrigated and not irrigated treatments, respectively. The arrows in the figure indicate the $\mathrm{CO}_{2}$ assimilation rate at the atmospheric $\mathrm{CO}_{2}$ concentration (from Lovelli et al., 2010c).

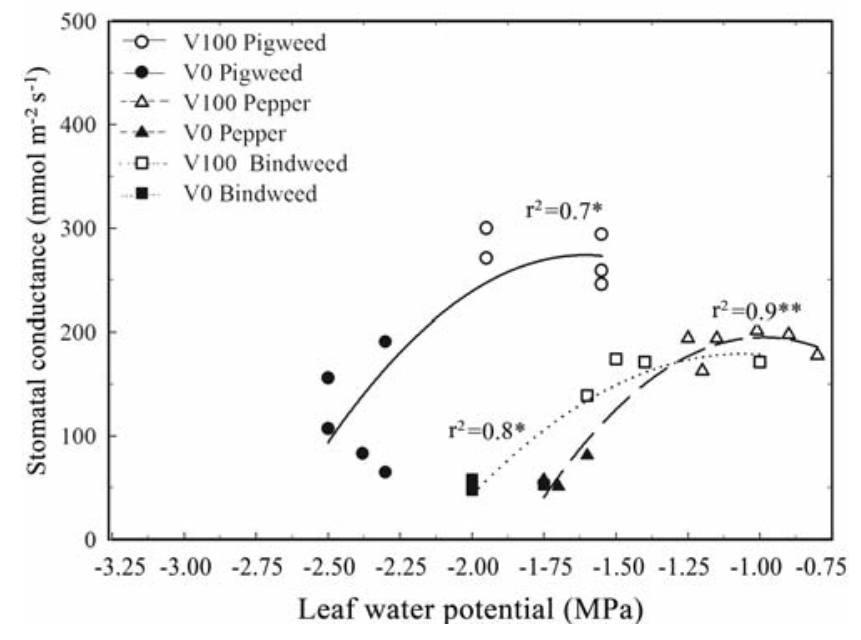

Figure 4. Stomatal water vapour conductance as a function of leaf water potential measured on pepper, pigweed and field bindweed leaves for the irrigated treatment (V100, open symbols, all data measured) and not irrigated treatment (V0, closed symbols, all data measured). Data were fit using non linear regression analysis. Lines are polynomial fit for all data points (from Lovelli et al., 2010a). 


\section{Conclusions}

As climate becomes more uncertain, and the incidence of extreme events increases, water will become a key factor in maintaining agricultural productivity in the Mediterranean. In this region the temperature rise and the concomitant expected rainfall reduction may lead to an increase in yearly water deficit. For autumn-spring crops a further increase of water deficit is not expected. In contrast, for spring-summer crops a significant increase of water deficit, and thus of irrigation demand, is anticipated. In our climate simulations for crops growing in the spring-summer period the increase in evapotranspirative demand is not compensated by stomatal closure. In addition, our field trials suggest that weed competition may already be increasing due to a warmer climate in the Mediterranean region. The implications of this on crop water use and crop coefficients are unclear.

We would emphasize that there have been few field studies of how temperature, drought and rising $\mathrm{CO}_{2}$ interact in affecting water use and irrigation demand of major agronomic crops (Long and Ort, 2010). There are GCM predictions regarding production and water availability, but in situ adaptive strategies have not always been elucidated. Given the importance of the Mediterannean region to the food security interests of Europe and Africa, and the importance of water in this region, that there is a critical need for additional research in this area as a means to limit future climate change impacts.

\section{References}

Ainsworth EA, Long SP, 2005. What have we learned from 15 years of free-air $\mathrm{CO}_{2}$ enrichment (FACE)? A meta-analytic review of the responses of photosynthesis, canopy properties and plant production to rising $\mathrm{CO}_{2}$. New Phytol. 165:351-372.

Allen RG, Pereira LS, Raes D, Smith M, 1998. Crop evapotranspiration. Guidelines for computing crop water requirements. FAO Irrigation and Drainage paper 56. FA0 Publ., Roma, Italy.

Allen RG, Pruitt WO, Wright JL, Howell TA, Ventura F, Snyder R, Itenfisu D, Steduto P, Berengena J, Yrisarry BJ, Smith M, Pereira LS, Raes D, Perrier A, Alves I,Walter I, Elliott R., 2006. A recommendation on standardized surface resistance for hourly calculation of reference ETo by the FA056 Penman-Monteith method. Agr. Water Manage. 81:1-22.

Baldocchi D, 1994. A comparative study of mass and energy exchange rates over a closed $\mathrm{C} 3$ (wheat) and an open $\mathrm{C} 4$ (corn) crop: II. $\mathrm{CO}_{2}$ exchange and water use efficiency. Agr. Forest. Meteorol. 67:291321.

Benvenuti S, 2009. Potenziale impatto dei cambiamenti climatici nell'evoluzione floristica di fitocenosi spontanee in agroecosistemi mediterranei. Ital. J. Agron. 4(Suppl.1):45-67.

Bernacchi CJ, Kimball BA, Quarles DR, Long SP, Ort DR, 2007. Decreases in stomatal conductance of soybean under open-air elevation of $\left[\mathrm{CO}_{2}\right]$ are closely coupled with decreases in ecosystem evapotranspiration. Plant Physiol. 143:134-144.

Bindi M, Ferrini F, Miglietta F, 1992. Climatic change and the shift in the cultivated area of olive trees. Agricoltura Mediterranea 22:4144.

Bindi M, Fibbi L, Gozzini B, Orlandini S, Miglietta F, 1996. Modelling the impact of future climate scenarios on yield and yield variability of grapevine. Climate Res. 7:213-224.

Bindi M, Fibbi L, Maselli F, Miglietta F, 2000. Modelling climate change impacts on grapevine in Tuscany. In: T.E. Downing, P.A. Harrison, R.E. Butterfield and K.G. Lonsdale (eds.) Climate Change, Climate Variability and Agriculture in Europe: An Integrated Assessment.
Research Report 21, Environmental Change Unit, University of Oxford Publ., Oxford, UK.

Brutsaert WH, Stricker H, 1979. An advection aridity approach to estimate actual regional evapotranspiration. Water Resour. Res. 15:443-450.

Cobb AH, Reade JPH, 2010. Herbicides and plant physiology, 2nd ed. Wiley-Blackwell, Oxford, UK, pp 14-15.

Dai A, 2010. Drought under global warming: a review. Wiley Interdisciplinary Reviews: Climate Change 2:45-65.

Döll P, 2002. Impact of climate change and variability on irrigation requirements: a global perspective. Climatic Change 54:269-293.

Drake BG, Gonzalez-Meler MA, Long SP, 1997. More efficient plants:a consequence of rising atmospheric $\mathrm{CO}_{2}$ ? Annu. Rev. Plant Physiol. Plant Mol. Biol. 48:609-639.

Fink AH, Brucher T, Kruger A, Leckebusch GC, Pinto JG, Ulbrich U. 2004. The 2003 European summer heatwaves and drought - synoptic diagnosis and impacts. Weather 59:209-216.

Ghannoum 0, von Caemmerer S, Ziska LH, Conroy JP, 2000. The growth response of $\mathrm{C} 4$ plants to rising atmospheric $\mathrm{CO}_{2}$ partial pressure: a reassessment. Plant Cell Environ. 23:931-942.

Giorgi F, Hewitson B, Christensen J, Fu C, 2001. Regional climate information: evaluation and projections, in Climate Change 2001: the scientific basis. Contribution of Working Group I to the Third Assessment Report of the Intergovernmental Panel on Climate Change. Cambridge University Press, Cambridge, UK, pp 583-638.

Goyal RK, 2004. Sensivity of evapotranspiration to global warming: a case study of arid zone of Rajasthan (India). Agric. Water Manage. 69:1-11.

Grise DJ, 1996. Effects of elevated $\mathrm{CO}_{2}$ and high temperature on the relative growth rates and competitive interactions between a $\mathrm{C} 3$ (Chenopodium album) and a C4 (Amaranthus hybridus) annual. Degree Diss., University of Georgia, USA.

Harley PC, Thomas RB, Reynolds JF, Strain BR, 1992. Modelling photosynthesis of cotton grown in elevated $\mathrm{CO}_{2}$. Plant Cell Environ. 15:271-282.

Intergovernmental Panel on Climate Change. 2001. Climate change 2001: the scientific basis. Contribution of Working Group I to the Third Assessment Report of the Intergovernmental Panel on Climate Change. Cambridge University Press, New York, NY, USA.

IPCC, Qin D, Manning M, Chen Z, Marquis M, Averyt KB, Tignor M, Miller HL, 2007. IPCC Summary for Policymakers. In: Climate Change 2007: The Physical Science Basis. Contribution of Working Group I to the Fourth Assessment Report of the Intergovernmental Panel on Climate Change. Cambridge University Press, New York, NY, USA.

Kimball BA, 2004. Global environmental change: implications for agricultural productivity. Crop Environ. Bioinform. 1:251-263

Kostopoulou E, Jones PD, 2005. Assesment of climate extremes in the eastern Mediterranean. Meteorol. Atmos. Phys. 89:69-85.

Lobell DB, Schlenker W, Costa-Roberts J, 2011. Climate trends and global crop production since 1980. Science DOI:10.1126/science.1204531.

Long SP, 1998. C4 photosynthesis - environmental responses. In: R.F. Sage and R.K. Monson (eds.) The biology of C4 photosynthesis. Academic Press, San Diego, CA, USA.

Long SP, 1999. Environmental responses. In: R.F. Sage and R.K. Monson (eds.) The biology of $\mathrm{C} 4$ photosynthesis. Academic Press, San Diego, CA, USA.

Long SP, Ort DR, 2010. More than taking the heat: crops and global change. Curr. Opin. Plant Biol. 13:241-248.

Lovelli S, Di Tommaso T, Amato M, Valerio M, Perniola M, 2010a. Competition between weeds and pepper cultivated in Southern Italy. Ital. J. Agron. 5:257-264.

Lovelli S, Perniola M, Di Tommaso T, Ventrella D, Moriondo M, Amato 
$\mathrm{M}, 2010 \mathrm{~b}$. Effects of rising atmospheric $\mathrm{CO}_{2}$ on crop evapotranspiration in a Mediterranean area. Agr. Water Manage. 97:1287-1292.

Lovelli S, Perniola M, Ferrara A, Amato M, Di Tommaso T, 2010c. Photosynthetic response to water stress of pigweed (Amaranthus retroflexus L.) in a Southern-Mediterranean area. Weed Science 58:126-131.

Ludlow MM, 1985. Photosynthesis and dry matter production in C3 and C4 pasture plants, with special emphasis on tropical C3 legumes and grasses. Aust. J. Plant. Physiol. 12:557-572.

McMaster GS, Wilhelm WW, 1997. Growing degree days: one equation, two interpretations. Agr. Forest Metereol. 87:291-300

McNaughton KG, 1983. Predicting effects of vegetation changes on transpiration and evaporation. Accademic Press, New York, NY, USA.

Moratiel R, Duran JM, Snyder RL, 2010. Responses of references evapotranspiration to changes in atmospheric humidity and air temperature in Spain. Climate Res. 44:27-40.

Morecroft MD, Roberts JM, 1999. Photosynthesis and stomatal conductance of mature canopy Oak (Quercus robur) and Sycamore (Acer pseudoplatanus) trees throughout the growing season. Funct. Ecol. 13:332-342.

Nakicenovic N, Alcamo J, Davis G, de Vries B, Fenhann J, Gaffin S, Gregory K, Grübler A, Jung TY, Kram T, La Rovere EL, Michaelis L, Mori S, Morita T, Pepper W, Pitcher H, Price L, Raihi K, Roehrl A, Rogner HH, Sankovski A, Schlesinger M, Shukla P, Smith S, Swart R, van Rooijen S, Victor N, Dadid Z, 2000. Emissions Scenarios. A Special Report of Working Group III of the Intergovernmental Panel on Climate Change. Cambridge University Press, Cambridge, UK. Available from: http:/www.grida.no/climate/ipcc/emission/index. htm

Olesen JE, Bindi M, 2002. Consequences of climate change for European agricultural productivity, land use and policy. Eur. J. Agron. 16:239-262.

Peiris DR, Crawford JW, Grashoff C, Jefferies RA, Porter JR,Marshall B
1996. A simulation study of crop growth and development under climate change. Agr. Forest Meteorol. 79:271-287.

Polley HW, 2002. Implications of Atmospheric and climatic change for crop yield and water use efficiency. Crop Sci. 42:131-140.

Porter JR, 2005. Rising temperatures are likely to reduce crop yields. Nature 436:174-1174.

Rowell DP, Jones RG, 2006. Causes and uncertainty of future summer drying over Europe. Clim. Dynam. 27:281-299.

Sage R, Kubien D, 2003. Quo vadis C4? An ecophysiological perspective on global change and the future of $\mathrm{C} 4$ plants. Photosynth. Res. 77:209-225.

Vergni L, Todisco F, 2010. Spatio-temporal variability of precipitation, temperature and agricultural drought indices in Central Italy. Agr. Forest. Meteorol. 151:301-313.

Vitale D, Rana G, Soldo P, 2010. Trends and extremes analysis of daily weather data from a site in the Capitanata plain (Southern Italy). Ital. J. Agron. 5:133-143.

Wand SJE, Midgley GF, Michael HJ, Curtis PS, 1999. Responses of wild $\mathrm{C} 4$ and $\mathrm{C} 3$ grass (Poaceae) species to elevated atmospheric $\mathrm{CO}_{2}$ concentration: a meta-analytic test of current theories and perceptions. Global Change Biol. 5:723-741.

Wilson KB, Carlson TN, Bunce JA, 1999. Feedback significantly influences the simulated effect of $\mathrm{CO}_{2}$ on seasonal evapotranspiration from two agricultural species. Global Change Biol. 5:903-917.

Ziska LH, Faulkner S, Lydon J, 2004. Changes in biomass and root:shoot ratio of field-grown Canada thistle (Cirsium arvense), a noxious, invasive weed with elevated $\mathrm{CO}_{2}$ : implications for control with glyphosate. Weed Science 52:584-588.

Ziska LH, 2010. Elevated atmospheric carbon dioxide alters the impact of Canada thistle in no-till soybean. Field Crop. Res. 119:299-303. 